\title{
The Role of Cross-Linguistic Influences in the Multilingual Communicative Competence Acquisition: A Classroom Research in the Greek Primary School Based on the Use of Free Online Linguistic Resources
}

\author{
Eftychia Damaskou \\ University of Thessaly, Greece
}

\begin{abstract}
The Council of Europe promotes the development of multilingual communicative competence, whereas many studies focus on the development of multilingual awareness in children. The main goal of our article is to study the effectiveness of online linguistic resources on the development of multilingual communicative competence, through a cross-linguistic study of several foreign languages. In specific, the necessary linguistic material was retrieved exclusively from free online resources. The survey was held over 117 5th and 6th graders in the Greek primary education. The activities presented the same linguistic content in four, unknown languages to the pupils: Dutch, Hungarian, Swedish and Portuguese. Internet offers very important auxiliary tools for teaching materials' development for a multilingual awareness, provided that they are not used unreasonably, but in an appropriate way so as to equip teacher with valid teaching material. Analysis of the data received from both the pupils' answer sheets but also from the verification process of the validity and effectiveness of the linguistic content retrieved from the online tools shows a significant difference between words and sentences' translation accuracy, mainly regarding online translators with many languages. However, the analysis of the pupils' worksheets shows relatively high scores, which means that online linguistic resources can be used only in accordance with the learning goals.
\end{abstract}

\section{Introduction}

The Council of Europe integrates the foreign languages learning in the framework of the development of a plurilingual competence but also the valorization of the individual's linguistic repertoire [6], [7]. The notion of "plurilingual competence" can be considered as the development of a composite repertoire, original and complex, where the different languages in contact interact and combine. Therefore language alternation could help promote metalinguistic awareness through the communicative use of more than two languages [2] [3], [4], [10]. According to the Common European Framework of Reference for Languages:

"Plurilingual and pluricultural competence

refers to the ability to use languages for the purposes of communication and to take part in intercultural interaction, where a person, viewed as a social agent has proficiency, of varying degrees, in several languages and experience of several cultures. This is not seen as the superposition or juxtaposition of distinct competences, but rather as the existence of a complex or even composite competence on which the user may draw." [4], [6]

It's true that working with many languages in the classroom may seem a quite hard task, or even impossible, however, this doesn't mean that these languages should be learnt by the pupils. In fact, it's about teaching pupils how to pass from one language to the other, make them discover their genealogical connection or loanword relationships that unite them, subtend affinities and establish inter-comprehension strategies.

Educate to diversity allows the implication of the whole personal development as well as the pupil's identity, through experiences based on the affinities and the differences among the languages. Besides every speaker has their own pluralistic resources which they combine in order to build up their linguistic repertoire. In addition, every pupil disposes of linguistic, cultural and social interactions either conscious or not, which highlight the linguistic intercomprehension.

As regards the pedagogical use of ICT in language teaching, this is one of the ordinary teachers' practices, through the use of multimodal resources and technical possibilities. The Council of Europe places language learning in the framework of multilingual competence development, as well as the valorization of the individuals' language repertoire [6], [7]. As regards the development of multilingual competence, Internet offers an important variety of language resources, such as online multilingual dictionaries, automatic translators, text to speech software.

This presentation will bring in our personal experience in the creation of teaching material for the development of multilingual communicative competence, using exclusively online machine translation tools. Given the fact that the teacher is not obliged to speak many foreign languages, the main goals of our study were to confirm if the multilingual communicative competence can be developed by drawing the necessary linguistic material exclusively 
on free online translation tools, but also consider the advantages, the disadvantages, as well as the limits of their use in language class. Thus, we must clarify that we have no intention to praise or to condemn the use of online translation tools, but to pinpoint the advantages as well as the limits of their use in a very precise learning context, which is the development of multilingual competence.

\section{Research Rationale}

Educational policies' declarations present an impressive unanimity as regards the implementation of digital educational practices in class [14], [21]. In general, there is a growing literature on the impact of Machine Translation (MT) on the language classroom [19]. For instance, there are some contributions which suggest how MT can be used as a kind of computer-assisted language learning tool. In addition, contrary to the studies working on the MT's positive impact on language learning, there are interesting approaches which seek to exploit the weaknesses of MT, in order to illustrate the differences between languages, or to raise learners' appreciation of questions regarding grammar and style [1], [8], [11], [15]. However, for Shei, incorporating MT in a second language teaching methodology is a relatively unexplored area, probably for two main reasons: firstly, because machine translation was disclaimed, and secondly, because of the fact that "there has been no place for translation to fit in under the reign of the Communicative Language Teaching approach since it emphasizes meaning-based communicative activities rather than static and conscious language practice" [17]. During the last years, free online machine translation tools are used in multilingual document retrieval and processing [18]. Free online translation system is the most accessible form of MT and it is mostly used in order to access the meaning of what a foreign text says [12]. In other words, free online MT outputs are not suitable for publication, as their system cannot be customized according to the language pair or the type of text and purposes (ibid.).

Niño addresses a list of positive and negative aspects of free online translators [12]. In particular, wide availability, immediacy, and a large range of languages appear to be among the positive features. In addition, online MT tools are effective with lexical translation as they can translate short lexical units reasonably well. Online MT tools are also good with repetitive and simply-structured texts, as they work reasonably well with not so complex structured texts such as weather reports or technical manuals.

On the other hand, outputs of free online translators include many errors and keep original structures of source languages. They also include many grammatical inaccuracies, producing inaccuracies in connectives and co-reference between the sentences. They also involve spelling errors and orthographical inaccuracies such as punctuation and capitalization errors, letter omissions or unnecessary letters. In addition, online MT tools are unable to account for cultural references and sometimes present unnatural writing. As regards students and language teachers' perception on online translation systems, according to a survey conducted by Niño, "while the students accepted free online translator positively, the teachers perceived that in the future, when the quality of the online translation systems' output is better, they can start thinking about incorporating MT into the language class" [12]. Furthermore, according to McCathy, the use of online MT is usually due to a lack of time, energy, imagination, linguistic insight or a lack of confidence. However, according to Steding, teachers should also be aware that a large number of online translation services very often use the same third party products, which is a reason why different website produce identical translation mistakes. Besides, Anderson specifies that "the current major Machine Translation evaluation effort $[\ldots]$ shows that when compared to expert human translators, MT systems perform only about $65 \%$ as well on the average" [1], [20].

In order to consider how online machine translators could be useful in the development of multilingual competence, we should firstly clarify its definition. So, talking about multilingual competence we do not only refer to the knowledge of many languages along with the experience of many cultures, but also to the individual's ability to handle the total of this linguistic and cultural capital [6]. The multilingual competence is neither the superimposition, nor the juxtaposition of distinct competences, but quite the opposite it is about a complex competence, which embraces mediations and passing arrays between languages [5]. Internet is a dynamic medium, which provides teachers and students with immediate access to tools and resources [16]. In particular, working on multilingual competence development in class requires a large amount of linguistic valid resources. This would be impossible for the teacher, if it wasn't for the free online language resources, such as online multilingual dictionaries or online machine translators. In the following section we are going to present a research that we personally conceived and conducted, in order to study if the teacher can rely on online machine translators in order to develop within their pupils a multilingual competence. Finally, as regards the use of text to speech software in the foreign language class, the respective literature, is quite limited and mainly concerns the improvement of pronunciation, and reading skills [9], [13]. 


\section{The Research}

\subsection{Research Methodology}

Our research consists on a teaching unit personally conceived. The theme was "Invite a foreign friend to my house" and the mails goals were: raise pupils' awareness on European multilingualism, develop pupils' metalinguistic competences, valorization of pupils' linguistic repertoire, knowledge transfer and learning strategies, raise pupils' phonological awareness, limit stereotypes about foreign languages, raise awareness of linguistic similarities and differences, study linguistic similarities and differences through a cross-linguistic approach, raise familiarity with syntax, lexicon and morphology of foreign languages, develop multilingual communicative competence. Our sample involved 117 5th and 6th graders in 6 Primary Schools in the region of Evros (Northern Greece). One of the participating classes (11 pupils) served as a pilot group, in order to check the duration, but also the quality of the equipment and the format of the material used.

Our experiment was based on a sequence of six activities personally conceived and designed. The proposed activities invited pupils to study in parallel, four unknown to them foreign languages: Hungarian, Dutch, Portuguese and Swedish. The activities' subject was to give instructions to a foreign friend in their mother tongue, to come to their house. Thus, the activities invited pupils to a parallel work on the same linguistic content (vocabulary, grammar and syntax) in 4 unknown languages (Hungarian, Swedish, Dutch and Portuguese), including all four linguistic skills (written and oral comprehension and production). We also minded to diversify the type of the activities (matching activities, multiple choices, brainstorming, and free production). Our language selection criteria were: the Dutch because it is a relative language to English and German, the Swedish because it is not very popular in Greece although the masses of Scandinavian tourists visiting Greece during summer, the Portuguese because it is related to French (the 2nd foreign language learnt by the pupils at school) and, finally, the Hungarian because it has no relation with any other European language. Concerning the linguistic material's fixing, scouting and crosscheck, we applied the following method: a) determination of the linguistic material aligned to the learning objectives, b) linguistic material' detection and listing in the chosen languages, and finally c) crosscheck of the material's correctness and validity made by native speakers. The subject's selection criteria were: vocabulary similarity, compatibility of the aimed competences with those already developed in other foreign languages taught at school.
The data collection tools of our research involve the pupils' worksheets, a questionnaire concerning pupils' attitudes, impressions and developed competences towards the studied languages. The online resources used for the detection of the necessary linguistic content as well as the verification of the grammatical, orthographic and syntactic correctness were: a search engine, four free online translators and the site http://www.voki.com which offers a free text to speech software in many languages. The correctness of the linguistic material retrieved by the online translators was verified by native speakers in the respective languages. The criteria for the use of these translation tools were: free accessibility, no cost, immediateness, ergonomic words' treatment (copy-paste) and finally the variety of possible combinations among languages. We chose to use more than one translator, in order to avoid targeting a specific online translator, but also extract global and more valid output.

The pupils were invited to think out loud, through a guided discussion, based on metalinguistic conceptualization of lexical, morphological and syntactical structures of the studied languages, with a view to develop multilingual communicative competences. Through the cross-linguistic simultaneity, pupils capitalized on the already known elements of the sentences proposed (words, numbers, etc.), as well as linguistic similarities, in order to discover the meaning of the sentences. Our data were gathered through our personal logbook, as well as the written answers given by our sample. The findings are very satisfying and encouraging, as they reveal speed, accuracy and language correctness in the texts produced. In addition, the activities proposed "activated" metalinguistic skills and cognitive transfer, whereas the cross-linguistic influences and the inter-comprehension assured the acquisition of multilingual competences.

\subsection{Research Tool}

The pedagogical and technical features of the teaching unit were the following:

\begin{tabular}{cc}
\hline $\begin{array}{c}\text { Period of } \\
\text { realisation }\end{array}$ & May-June 2013 \\
\hline Duration & 3 teaching hours \\
\hline $\begin{array}{c}\text { Teaching } \\
\text { method }\end{array}$ & $\begin{array}{c}\text { frontal teaching (presentation- explanation of the activities), } \\
\text { interactive teaching (presentation of the answers) }\end{array}$ \\
$\begin{array}{c}\text { Pupils' working } \\
\text { method }\end{array}$ & individual for the activities $1,2,3$ and 6 and in pairs for the activities 4 \\
teacher's role & and 5 \\
\hline
\end{tabular}

Table 1 presents the instructions given in each activity. 
Table 1. Activities' instructions

\begin{tabular}{|c|c|c|}
\hline & Instruction & Goals \\
\hline Activity 1 & $\begin{array}{l}\text { You are going to listen to four groups } \\
\text { of words. Guess in which language } \\
\text { they are: Portuguese, Dutch, Swedish } \\
\text { or Hungarian? }\end{array}$ & $\begin{array}{l}\text { auditory discrimination } \\
\text { development, linguistic repertoire } \\
\text { utilization, awareness of unknown } \\
\text { foreign language }\end{array}$ \\
\hline Activity 2 & $\begin{array}{l}\text { You are going to listen to the same } \\
\text { groups of words. Try to match what } \\
\text { you hear with one of the following } \\
\text { groups. }\end{array}$ & $\begin{array}{l}\text { understanding of the link between } \\
\text { written and spoken forms, } \\
\text { auditory discrimination of the } \\
\text { sounds that correspond the same } \\
\text { letter (i.e. a, â, ă, ä, å, s, ş), } \\
\text { improve familiarity with those } \\
\text { symbols, raise awareness of the } \\
\text { affinities and differences between } \\
\text { languages }\end{array}$ \\
\hline Activity 3 & $\begin{array}{l}\text { Cross out the word that does not match } \\
\text { with the others. }\end{array}$ & $\begin{array}{l}\text { Raise awareness of the affinities } \\
\text { and differences between } \\
\text { languages, raise awareness of the } \\
\text { relationships between languages } \\
\text { (genetic relationship or } \\
\text { loanwords), improve familiarity } \\
\text { with morphology and syntax in } \\
\text { relative languages. }\end{array}$ \\
\hline Activity 4 & $\begin{array}{l}\text { Observe the following arrows. } \\
\text { Towards which direction should we } \\
\text { turn in order to go to school, to the } \\
\text { park, to the museum, to the police } \\
\text { station, and to the hospital? }\end{array}$ & $\begin{array}{l}\text { utilization of previous lexical } \\
\text { competences, comparison, and } \\
\text { analysis strategies development, } \\
\text { knowledge transfer. }\end{array}$ \\
\hline Activity 5 & $\begin{array}{l}\text { Observe the following sentences: a) } \\
\text { underline the words that you already } \\
\text { know or those that ring you a bell, b) } \\
\text { Guess in which language they are } \\
\text { (Portuguese, Hungarian, Dutch or } \\
\text { Swedish), and c) try to find their } \\
\text { meaning }\end{array}$ & $\begin{array}{l}\text { activate and apply prior } \\
\text { knowledge, raise familiarity with } \\
\text { syntax and morphology of } \\
\text { unknown foreign languages, } \\
\text { conceptualization of sentence } \\
\text { structure in a foreign language, } \\
\text { develop cognitive strategies to } \\
\text { analyze, compare and synthesize, } \\
\text { raise awareness of linguistic } \\
\text { similarity. }\end{array}$ \\
\hline
\end{tabular}




\begin{tabular}{ll}
\hline Activity 6 & Anvite a friend to my house, give \\
Portuguese/Hungarian/Swedish/Dutch & directions, write the heading of a \\
friend of yours would like to visit you. letter and a closing sentence, learn \\
You are sending them an email to their common names in the countries of \\
language in order to explain how they the studied languages, opening \\
could get to your home. Fill in the and encouragement for the use of \\
following email form by putting the the Other's language in order to \\
words that you are given in the communicate \\
following order: I leave 30 Venizelou \\
street. Take the bus number 40 and get \\
off at "Venizelou" station. My house is \\
next to the post office. Go straight \\
ahead and turn right.If you choose for \\
Swedish, your text should start with \\
Tja Sven and end with hej då. For \\
Dutch, start with Hallo Willen and end \\
with dag. For Portuguese, start with \\
Olá Felipe and end with adeus. For \\
Hungarian, start with Héllo Agoston \\
and end with Szia. After writing the \\
email, fill the following map with the \\
correct indications.
\end{tabular}

\subsection{Research results}

The output received by the MT used in order to find the linguistic content needed for the first three activities of our teaching unit is presented in the following Tables (see Table 2, 3, 4 and 5):

Table 2. The words retrieved from the first MT

\begin{tabular}{|c|c|c|c|c|}
\hline $\begin{array}{l}\text { (Greek as language } \\
\text { source) }\end{array}$ & Swedish & Dutch & Portuguese & Hungarian \\
\hline 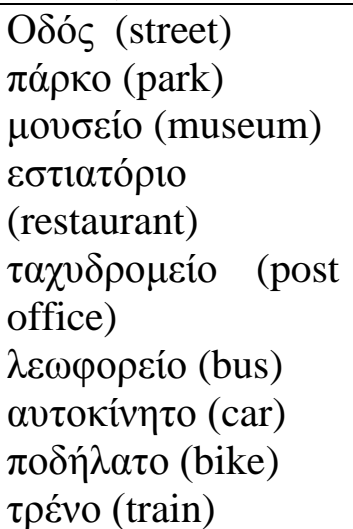 & $\begin{array}{l}\text { gata } \\
\text { park } \\
\text { museum } \\
\text { Restaurang } \\
\text { post } \\
\text { buss } \\
\text { bil } \\
\text { cykel } \\
\text { tåg }\end{array}$ & $\begin{array}{l}\text { straat } \\
\text { park } \\
\text { museum } \\
\text { restaurant } \\
\text { mail } \\
\text { bus } \\
\text { auto } \\
\text { fiets } \\
\text { trein }\end{array}$ & $\begin{array}{l}\text { rua } \\
\text { parque } \\
\text { museu } \\
\text { restaurante } \\
\text { correio } \\
\text { ônibus } \\
\text { carro } \\
\text { bicicleta } \\
\text { trem }\end{array}$ & $\begin{array}{l}\text { utca } \\
\text { park } \\
\text { múzeum } \\
\text { étterem } \\
\text { levél } \\
\text { busz } \\
\text { autó } \\
\text { bicikli } \\
\text { vonat }\end{array}$ \\
\hline
\end{tabular}

Table 3. The words retrieved from the second MT

\begin{tabular}{|c|c|c|c|c|}
\hline & Swedish & Dutch & Portuguese & Hungarian \\
\hline 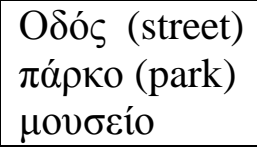 & $\begin{array}{l}\text { Gata, } \\
\text { park } \\
\text { museum }\end{array}$ & $\begin{array}{l}\text { Street } \\
\text { park } \\
\text { museum }\end{array}$ & $\begin{array}{l}\text { Street } \\
\text { park } \\
\text { museu }\end{array}$ & $\begin{array}{l}\text { Utca } \\
\text { park } \\
\text { múzeum }\end{array}$ \\
\hline
\end{tabular}




\begin{tabular}{|c|c|c|c|c|}
\hline 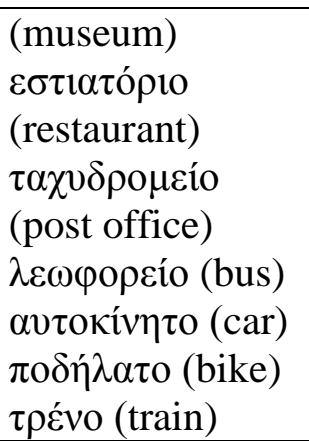 & $\begin{array}{l}\text { restaurang } \\
\text { post } \\
\text { buss } \\
\text { bil } \\
\text { cykel } \\
\text { tåg }\end{array}$ & $\begin{array}{l}\text { restaurant } \\
\text { postkantoor } \\
\text { bus } \\
\text { auto } \\
\text { fiets } \\
\text { trein }\end{array}$ & $\begin{array}{l}\text { restaurante } \\
\text { posto de } \\
\text { correios } \\
\text { ônibus } \\
\text { carro } \\
\text { bicicleta } \\
\text { comboio }\end{array}$ & $\begin{array}{l}\text { étterem } \\
\text { posta } \\
\text { busz } \\
\text { autó } \\
\text { kerékpár } \\
\text { vonat }\end{array}$ \\
\hline
\end{tabular}

Table 4. The words retrieved from the third MT

\begin{tabular}{|c|c|c|c|c|}
\hline & Swedish & Dutch & Portuguese & Hungarian \\
\hline 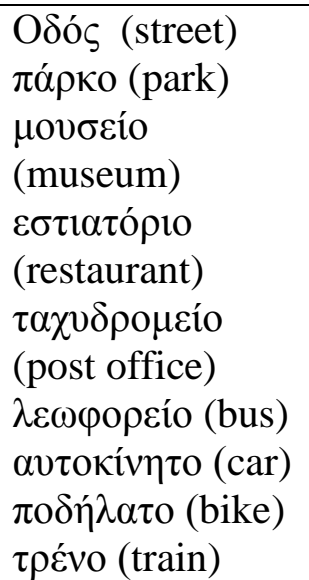 & $\begin{array}{l}\text { Gata, } \\
\text { park } \\
\text { museum } \\
\text { restaurang } \\
\text { post } \\
\text { buss } \\
\text { bil } \\
\text { cykel } \\
\text { tåg }\end{array}$ & $\begin{array}{l}\text { Street } \\
\text { park } \\
\text { museum } \\
\text { restaurant } \\
\text { postkantoor } \\
\text { bus } \\
\text { auto } \\
\text { fiets } \\
\text { trein }\end{array}$ & $\begin{array}{l}\text { Street } \\
\text { park } \\
\text { museu } \\
\text { restaurante } \\
\text { posto } \\
\text { correios } \\
\text { ônibus } \\
\text { carro } \\
\text { bicicleta } \\
\text { comboio }\end{array}$ & $\begin{array}{l}\text { Utca } \\
\text { park } \\
\text { múzeum } \\
\text { étterem } \\
\text { posta } \\
\text { busz } \\
\text { autó } \\
\text { kerékpár } \\
\text { vonat }\end{array}$ \\
\hline
\end{tabular}

Table 5. The words retrieved from the fourth MT

\begin{tabular}{|c|c|c|c|c|}
\hline & Swedish & Dutch & Portuguese & Hungarian \\
\hline 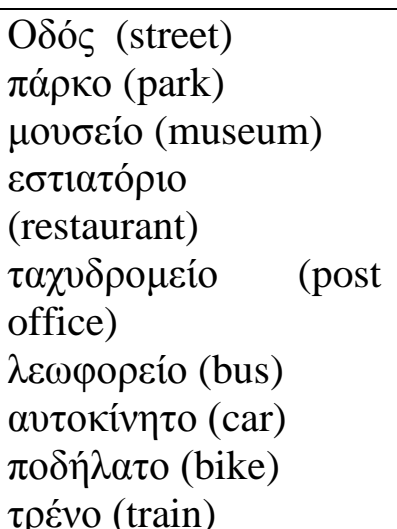 & $\begin{array}{l}\text { Gata, } \\
\text { park } \\
\text { museum } \\
\text { restaurang } \\
\text { post } \\
\text { buss } \\
\text { bil } \\
\text { cykel } \\
\text { tåg }\end{array}$ & $\begin{array}{l}\text { Street } \\
\text { park } \\
\text { museum } \\
\text { restaurant } \\
\text { postkantoor } \\
\text { bus } \\
\text { auto } \\
\text { fiets } \\
\text { trein }\end{array}$ & $\begin{array}{l}\text { Street } \\
\text { park } \\
\text { museu } \\
\text { restaurante } \\
\text { posto de } \\
\text { correios } \\
\text { ônibus } \\
\text { carro } \\
\text { bicicleta } \\
\text { comboio }\end{array}$ & $\begin{array}{l}\text { Utca } \\
\text { park } \\
\text { múzeum } \\
\text { étterem } \\
\text { posta } \\
\text { busz } \\
\text { autó } \\
\text { kerékpár } \\
\text { vonat }\end{array}$ \\
\hline
\end{tabular}

Four native speakers (one for each language) were asked to correct and to comment on the sentences given by the online translators. All of them asked for the original sentences as they couldn't even guess the meaning of some of the sentences. The following tables present the results given by the MT for the sentences in the 5th activity. The source language was Greek, our mother tongue. In the following Tables (Tables 6 to 10) we present the output retrieved from the online translators. 
Table 6. The sentences retrieved for the $5^{\text {th }}$ activity for Swedish

\begin{tabular}{|c|c|c|c|c|c|}
\hline $\begin{array}{r}\text { Source } \\
\text { Sentence }\end{array}$ & MT1 & MT3 & MT2 & MT4 & $\begin{array}{c}\text { Native } \\
\text { speaker }\end{array}$ \\
\hline $\begin{array}{c}\text { I live in } \\
30, \\
\text { Venizelou } \\
\text { street }\end{array}$ & $\begin{array}{c}\text { Jag återstår } \\
\text { i vägen } \\
\text { Benizeloy } 30 .\end{array}$ & $\begin{array}{l}\text { Jag bor på } \\
30 \text { Venizelos }\end{array}$ & $\begin{array}{c}\text { JAG } \\
\text { Venizelou } \\
\text { street } 30\end{array}$ & $\begin{array}{c}\text { Jag bor i } \\
30, \\
\text { Venizelou } \\
\text { street }\end{array}$ & $\begin{array}{c}\text { Jag bor } \\
\text { på gatan } \\
\text { Venizelou } \\
30\end{array}$ \\
\hline $\begin{array}{c}\text { Take the } \\
\text { bus number } \\
40 \text { and get } \\
\text { off at the } \\
\text { station } \\
\text { "Venizelou" }\end{array}$ & $\begin{array}{c}\text { Ta bussa } \\
\text { numrerar } 40 \\
\text { och får av på } \\
\text { postera } \\
\text { "Venizelou", }\end{array}$ & $\begin{array}{c}\text { Ta buss } \\
\text { nummer } 40 \\
\text { och stig av } \\
\text { vid Venizelos }\end{array}$ & $\begin{array}{c}\text { Ta buss } \\
\text { nummer } 40 \\
\text { och att } \\
\text { avbryta } \\
\text { Venizelou }\end{array}$ & $\begin{array}{c}\text { Ta buss } \\
\text { nummer } 40 \\
\text { och gå av vid } \\
\text { stationen } \\
\text { "Venizelou" }\end{array}$ & $\begin{array}{c}\text { Ta buss } \\
40 \text { och gå } \\
\text { av vid } \\
\text { busshållspla } \\
\text { tsen } \\
\text { "Venizelou" }\end{array}$ \\
\hline $\begin{array}{l}\text { My house } \\
\text { is next to the } \\
\text { post office. }\end{array}$ & $\begin{array}{l}\text { Mitt hus är } \\
\text { bredvid t-nolla } \\
\text { postar }\end{array}$ & $\begin{array}{l}\text { Mitt hus } \\
\text { ligger } \\
\text { bredvid } \\
\text { postkontoret }\end{array}$ & $\begin{array}{l}\text { Mitt hus } \\
\text { ligger intill } \\
\text { post }\end{array}$ & $\begin{array}{l}\text { Mitt hus } \\
\text { ligger } \\
\text { bredvid } \\
\text { postkontoret }\end{array}$ & $\begin{array}{l}\text { Mitt hus } \\
\text { är bredvid } \\
\text { posten }\end{array}$ \\
\hline $\begin{array}{l}\text { Keep on } \\
\text { going } \\
\text { straight } \\
\text { ahead and } \\
\text { turn right. }\end{array}$ & $\begin{array}{l}\text { Det som är } \\
\text { rakt på fortsatt } \\
\text { och vänd rätt }\end{array}$ & $\begin{array}{l}\text { Fortsätt } \\
\text { rakt och } \\
\text { sväng höger }\end{array}$ & $\begin{array}{l}\text { Fortsatt } \\
\text { rakt och gå åt } \\
\text { höger }\end{array}$ & $\begin{array}{l}\text { Hålla på } \\
\text { att gå rakt } \\
\text { fram och } \\
\text { sväng höger }\end{array}$ & $\begin{array}{l}\text { Sväng } \\
\text { höger och } \\
\text { fortsätt rakt } \\
\text { fram }\end{array}$ \\
\hline
\end{tabular}

Table 7. The sentences retrieved for the $5^{\text {th }}$ activity for Dutch

\begin{tabular}{|c|c|c|c|c|c|}
\hline $\begin{array}{c}\text { Source } \\
\text { Sentence }\end{array}$ & MT1 & MT3 & MT2 & MT4 & $\begin{array}{c}\text { Native } \\
\text { speaker }\end{array}$ \\
\hline $\begin{array}{l}\text { I live in } 30, \\
\text { Venizelou } \\
\text { street }\end{array}$ & $\begin{array}{c}\text { Ik blijf in } \\
\text { de weg } \\
\text { Benizeloy } 30\end{array}$ & $\begin{array}{l}\quad \text { Ik woon } \\
\text { op } 30 \\
\text { Venizelos }\end{array}$ & $\begin{array}{l}\text { IK woon in } \\
\text { Venizelou } \\
\text { street } 30\end{array}$ & $\begin{array}{c}\text { I live in } \\
\text { 30, } \\
\text { Venizelou } \\
\text { street }\end{array}$ & $\begin{array}{c}\text { Ik woon in } \\
\text { Venizelosstraat } \\
30\end{array}$ \\
\hline $\begin{array}{l}\quad \text { Take the } \\
\text { bus number } \\
40 \text { and get } \\
\text { off at the } \\
\text { station } \\
\text { "Venizelou" }\end{array}$ & $\begin{array}{l}\text { De } \\
\text { busnoymero } \\
40 \text { van Paros } \\
\text { en u daalt in } \\
\text { de houding } \\
\text { „Benizeloy“ }\end{array}$ & $\begin{array}{c}\text { Neem } \\
\text { bus } 40 \text { en } \\
\text { stap uit bij } \\
\text { "Venizelos" }\end{array}$ & $\begin{array}{l}\text { Neem bus } \\
\text { nummer } 40 \text { te } \\
\text { stoppen } \\
\text { "Venizelou" }\end{array}$ & \begin{tabular}{l}
\multicolumn{1}{c}{ Neem de } \\
buslijn 40 en \\
stap uit bij \\
station \\
"Venizelou"
\end{tabular} & $\begin{array}{l}\text { Neem bus } \\
40 \text { en stap bij } \\
\text { de halte } \\
\text { "Venizelou". }\end{array}$ \\
\hline $\begin{array}{l}\text { My house } \\
\text { is next to the } \\
\text { post office. }\end{array}$ & $\begin{array}{l}\text { Mijn huis } \\
\text { is naast to } \\
\text { post }\end{array}$ & \begin{tabular}{l}
\multicolumn{1}{c}{ Mijn } \\
huis ligt \\
naast het \\
postkantoor
\end{tabular} & $\begin{array}{l}\text { Mijn huis is } \\
\text { naast mail }\end{array}$ & $\begin{array}{l}\text { Mijn huis } \\
\text { is naast het } \\
\text { postkantoor }\end{array}$ & $\begin{array}{l}\text { Mijn huis } \\
\text { ligt naast het } \\
\text { postkantoor. }\end{array}$ \\
\hline
\end{tabular}




\begin{tabular}{|c|c|c|c|c|c|}
\hline $\begin{array}{l}\quad \text { Keep on } \\
\text { going } \\
\text { straight } \\
\text { ahead and } \\
\text { turn right }\end{array}$ & $\begin{array}{l}\quad \text { Het ging } \\
\text { rechtdoor } \\
\text { verder en } \\
\text { draait net }\end{array}$ & $\begin{array}{l}\quad \mathrm{Ga} \\
\text { rechtdoor } \\
\text { en sla } \\
\text { rechtsaf }\end{array}$ & $\begin{array}{l}\text { Verder } \\
\text { rechtdoor en } \\
\text { ga rechts }\end{array}$ & $\begin{array}{l}\quad \text { Blijf } \\
\text { rechtdoor en } \\
\text { rechtsaf. }\end{array}$ & $\begin{array}{l}\text { Sla rechtsaf } \\
\text { en ga } \\
\text { rechtdoor. }\end{array}$ \\
\hline
\end{tabular}

Table 8. The sentences retrieved for the $5^{\text {th }}$ activity for Portuguese

\begin{tabular}{|c|c|c|c|c|c|}
\hline $\begin{array}{c}\text { Source } \\
\text { Sentence }\end{array}$ & $\underline{\text { MT1 }}$ & MT3 & MT2 & MT4 & Native speaker \\
\hline $\begin{array}{c}\text { I live in } \\
\text { 30, } \\
\text { Venizelou } \\
\text { street }\end{array}$ & $\begin{array}{l}\text { Eu vivo } \\
\text { na estrada } \\
\text { Benizeloy } \\
30 .\end{array}$ & $\begin{array}{l}\text { Eu vivo } \\
\text { na rua } \\
\text { Venizelos } \\
30 .\end{array}$ & $\begin{array}{c}\text { Eu vivo } \\
\text { na rua } \\
\text { Venizelou } \\
30 .\end{array}$ & $\begin{array}{c}\text { Eu vivo } \\
\text { em 30h, rua } \\
\text { Venizelou }\end{array}$ & $\begin{array}{l}\text { Moro na rua } \\
\text { Venizelou } 30 .\end{array}$ \\
\hline $\begin{array}{l}\text { Take the } \\
\text { bus number } \\
40 \text { and get } \\
\text { off at the } \\
\text { station } \\
\text { "Venizelou" }\end{array}$ & $\begin{array}{c}\text { O noymero } \\
40 \text { e você } \\
\text { da barra- } \\
\text { ônibus de } \\
\text { Paros vai } \\
\text { para baixo } \\
\text { na atitude } \\
\text { "Benizeloy" }\end{array}$ & $\begin{array}{c}\text { Apanhe } \\
\text { o autocarro } \\
40 \text { e desça } \\
\text { na } \\
\text { "Venizelos" }\end{array}$ & $\begin{array}{l}\text { Apanhe } \\
\text { o autocarro } \\
\text { número } 40 \\
\text { e para parar } \\
\text { "Venizelos" }\end{array}$ & $\begin{array}{l}\text { Pegue o } \\
\text { ônibus } \\
\text { número } 40 \\
\text { e saia na } \\
\text { estação } \\
\text { "Venizelou" }\end{array}$ & $\begin{array}{c}\text { Apanha o } \\
\text { autocarro } 40 \text { e } \\
\text { desce na paragem } \\
\text { "Venizelou". }\end{array}$ \\
\hline $\begin{array}{c}\text { My } \\
\text { house is } \\
\text { next to the } \\
\text { post office. }\end{array}$ & $\begin{array}{c}\text { Minha } \\
\text { casa é ao } \\
\text { lado do } \\
\text { borne de to }\end{array}$ & $\begin{array}{c}\text { Minha } \\
\text { casa fica ao } \\
\text { lado da } \\
\text { estação de } \\
\text { correios }\end{array}$ & $\begin{array}{l}\text { A minha } \\
\text { casa é } \\
\text { próxima ao } \\
\text { correio }\end{array}$ & $\begin{array}{l}\text { A Minha } \\
\text { casa fica ao } \\
\text { lado dos } \\
\text { correios. }\end{array}$ & $\begin{array}{l}\text { A minha casa } \\
\text { ao lado dos } \\
\text { correios }\end{array}$ \\
\hline $\begin{array}{l}\text { Keep on } \\
\text { going } \\
\text { straight } \\
\text { ahead and } \\
\text { turn right. }\end{array}$ & $\begin{array}{c}\text { Ele em } \\
\text { linha reta } \\
\text { no } \\
\text { continuado } \\
\text { e voltas } \\
\text { para a } \\
\text { direita }\end{array}$ & $\begin{array}{l}\text { Continue } \\
\text { em frente e } \\
\text { vire à } \\
\text { direita }\end{array}$ & $\begin{array}{l}\text { Continuo } \\
\text { u reto e } \\
\text { navegar } \\
\text { direito }\end{array}$ & $\begin{array}{l}\text { Mantenh } \\
\text { a sempre } \\
\text { em frente e } \\
\text { vire à } \\
\text { direita. }\end{array}$ & $\begin{array}{l}\text { Vira à direita } \\
\text { segue em frente }\end{array}$ \\
\hline
\end{tabular}

Table 9. The sentences retrieved for the $5^{\text {th }}$ activity for Hungarian

\begin{tabular}{|l|l|l|l|l|l|}
\hline $\begin{array}{l}\text { Source } \\
\text { Sentence }\end{array}$ & MT1 & MT2 & MT4 & $\begin{array}{l}\text { Native } \\
\text { speaker }\end{array}$ \\
\hline $\begin{array}{l}\text { I live in 30, } \\
\text { Venizelou } \\
\text { street }\end{array}$ & $\begin{array}{l}\text { Én továbbra } \\
\text { is a közúti } \\
\text { Benizeloy 30 }\end{array}$ & $\begin{array}{l}\text { Én élek a a } \\
\text { Venizelou } \\
\text { utca 30 }\end{array}$ & $\begin{array}{l}\text { Élek 30 } \\
\text { Venizelosz. }\end{array}$ & $\begin{array}{l}\text { Én pedig élek } \\
\text { a Venizelou } \\
\text { utca 30 }\end{array}$ & $\begin{array}{l}\text { A Venizelou } \\
\text { utca 30-ban } \\
\text { lakom }\end{array}$ \\
\hline $\begin{array}{l}\text { Take the bus } \\
\text { number 40 } \\
\text { and get off } \\
\text { at the station }\end{array}$ & $\begin{array}{l}\text { Párosz } \\
\text { szigetéröl }\end{array}$ & $\begin{array}{l}\text { Azármazó } \\
\text { száma 40 és }\end{array}$ & $\begin{array}{l}\text { Busszal } \\
\text { arok hely }\end{array}$ & $\begin{array}{l}\text { Vegye le a áma és } \\
\text { busz száma } \\
\text { szálljon le a } \\
\text { 40, "romok" }\end{array}$ & $\begin{array}{l}\text { Szállj fel a 30- } \\
\text { as buszra és } \\
\text { szállj le a a } \\
\text { "Venizelou }\end{array}$ \\
\hline
\end{tabular}




\begin{tabular}{|l|l|l|l|l|l|}
\hline "Venizelou" & $\begin{array}{l}\text { noymero 40 } \\
\text { és menj le a } \\
\text { "Benizeloy" }\end{array}$ & megállónál \\
\hline $\begin{array}{l}\text { My house is } \\
\text { next to the } \\
\text { post office. }\end{array}$ & $\begin{array}{l}\text { A ház mellett } \\
\text { van a t o post }\end{array}$ & $\begin{array}{l}\text { A hellett van } \\
\text { a posta. }\end{array}$ & $\begin{array}{l}\text { A hellett á́z } \\
\text { posta }\end{array}$ & $\begin{array}{l}\text { A ház mellett } \\
\text { va a mail } \\
\text { connector }\end{array}$ & $\begin{array}{l}\text { A házam a } \\
\text { posta mellett } \\
\text { van. }\end{array}$ \\
\hline $\begin{array}{l}\text { Keep on } \\
\text { going } \\
\text { straight } \\
\text { ahead and } \\
\text { turn right. }\end{array}$ & $\begin{array}{l}\text { Tovább egyenesen és } \\
\text { jobbra forgó }\end{array}$ & $\begin{array}{l}\text { Menjen } \\
\text { egyenesen } \\
\text { előre és } \\
\text { jobbra. }\end{array}$ & $\begin{array}{l}\text { Tovább egyenesen } \\
\text { és jobbra }\end{array}$ & $\begin{array}{l}\text { Tovább egyenesen és } \\
\text { jobbra való } \\
\text { navigáláshoz }\end{array}$ & $\begin{array}{l}\text { Forduljon } \\
\text { jobbra } \\
\text { menjen } \\
\text { egyenesen. }\end{array}$ \\
\hline
\end{tabular}

Table 10. the output analysis of the translated phrases by the online translators

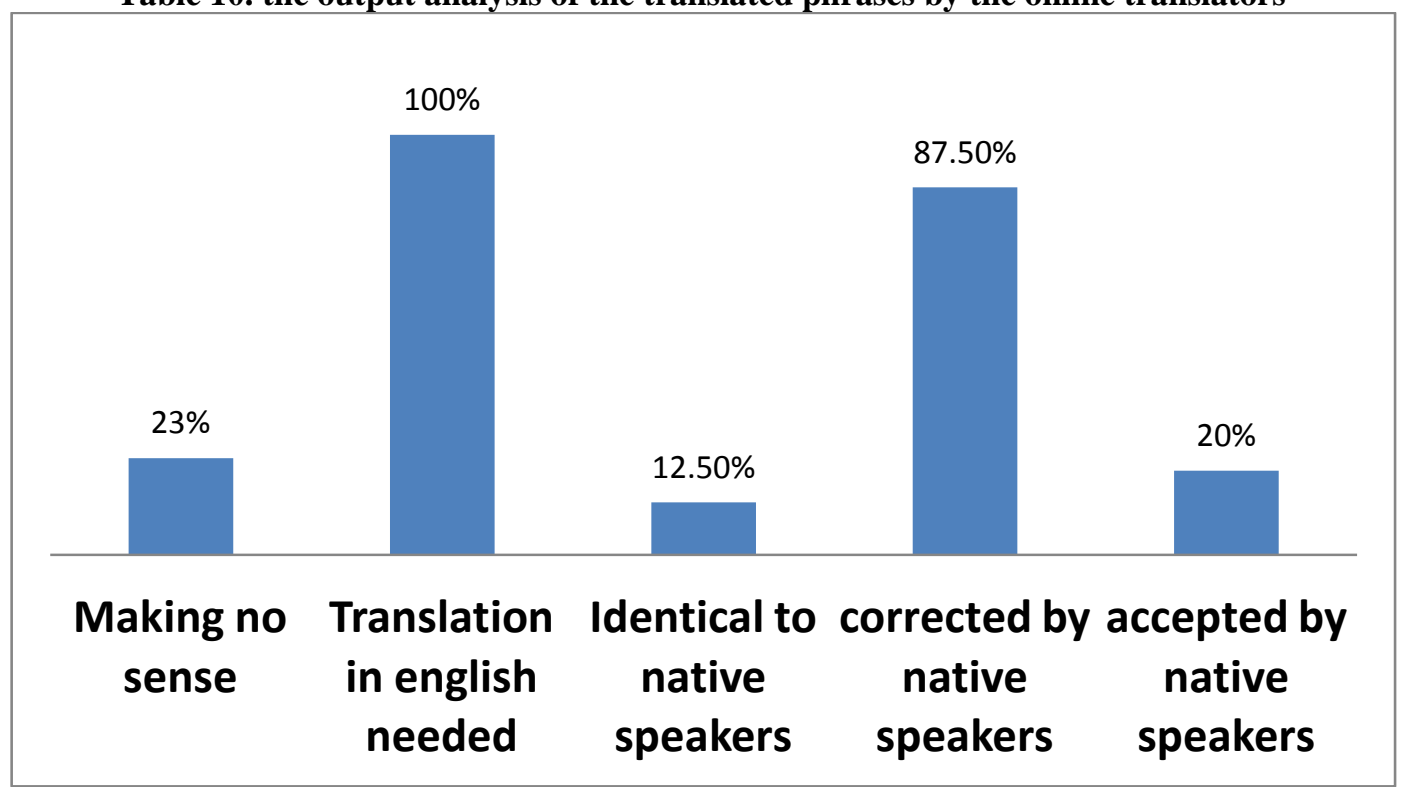

Analysis of the translations proposed by the online tools showed a significant difference between words and sentences' translation accuracy, mainly regarding online translators with many languages. The problems for the most part concern grammar and syntax, whereas lexical inappropriateness are less frequent, but still in some cases, we received different translations by different online translators for the same term. In fact, computer can only recognize word to word, so as it goes for communicative situations, there is also the pragmatological parameter which is involved, and which is not recognized by the computer.

The errors concerned mainly lexical, grammatical and spelling inaccuracies. In some cases, MT use synonyms (in Dutch weg Venizelos were weg means "road" instead of "street" as it was in the source language, in Swedish, Jag återstår i vägen Benizeloy 30 means I remain in the way Benizeloy 30, instead of I live in 30, Benizelou street). In other cases there were some irrelevant words that appeared in the sentence (Mijn huis is naast mail (NL), Ta buss nummer 40 och att avbryta Venizelou (SE) where avbryta means cancel, instead of get off ). There were also inappropriate syntactic structures (NL, Neem bus nummer 40 te stoppen "Venizelou" instead of Neem de bus nummer 40 en stop in de "Venizelou" stop). Finally there are also sentences without making any sense in the target language (De busnoymero 40 van Paros en $\mathrm{u}$ daalt in de houding $(\mathrm{NL}))$. As regards the Hungarian, we were very surprised to find out that the sentences retrieved from the MT were completely different, and had no common points.

The qualitative analysis of the pupils' worksheets leads us to the results represented in the following Table. The two first activities were conceived through the text to speech software available at www.voki.com. 
Table 11. Pupils' scores in activities 1 to 5

\begin{tabular}{|c|c|c|c|}
\hline & Correct answers & Wrong answers & No answer \\
\hline activity 1 & $\begin{array}{l}\mathrm{NL}=54 \\
\mathrm{PT}=51 \\
\mathrm{HU}=63 \\
\mathrm{SE}=44\end{array}$ & $\begin{array}{l}\mathrm{NL}=54 \\
\mathrm{PT}=51 \\
\mathrm{HU}=63 \\
\mathrm{SE}=44\end{array}$ & 14 \\
\hline activity 2 & $\begin{array}{l}\mathrm{NL}=90 \\
\mathrm{PT}=91 \\
\mathrm{HU}=89 \\
\mathrm{SE}=88\end{array}$ & $\begin{array}{l}\mathrm{NL}=14 \\
\mathrm{PT}=13 \\
\mathrm{HU}=15 \\
\mathrm{SE}=16\end{array}$ & 13 \\
\hline activity 3 & $\begin{array}{l}1^{\text {st }} \text { group }=104 \\
2^{\text {nd }} \text { group }=102 \\
3^{\text {rd }} \text { group }=89 \\
4^{\text {th }} \text { group }=91\end{array}$ & $\begin{array}{l}1^{\text {st }} \text { group }=5 \\
2^{\text {nd }} \text { group }=7 \\
3^{\text {rd }} \text { group }=20 \\
4^{\text {th }} \text { group }=18\end{array}$ & 8 \\
\hline activity 4 & 112 correct & none & 5 \\
\hline activity 5 & 79 correct & none & 38 incomplet \\
\hline
\end{tabular}

As regards the 6th activity, we retrieved the following data:

Table 11. Pupils' scores in the $6^{\text {th }}$ activity

\begin{tabular}{|c|c|c|c|c|c|c|}
\hline & $\begin{array}{l}\text { Totally } \\
\text { correct }\end{array}$ & $\begin{array}{l}\text { several } \\
\text { mistakes }\end{array}$ & $\begin{array}{l}\text { wrong } \\
\text { order }\end{array}$ & $\begin{array}{l}\text { many } \\
\text { mistakes }\end{array}$ & incomplete & $\begin{array}{l}\text { no } \\
\text { answer }\end{array}$ \\
\hline Swedish & 11 & & 5 & 1 & 3 & \multirow{4}{*}{13} \\
\hline Dutch & 18 & 3 & 6 & 1 & 6 & \\
\hline Hungarian & 18 & & 4 & 1 & 2 & \\
\hline Portuguese & 13 & & 2 & 2 & & \\
\hline
\end{tabular}

As we can see, pupils' scores are relatively high. For the first activities which mainly concerned vocabulary, we used the linguistic content retrieved from the online machine translators. We should also notice that pupils' performance progressively improves, and that in the last activity there are only several mistakes. However, regarding the 5th activity, we could not risk the validity of our work and so we chose to use the translation proposed by the native speakers.

As regards our questionnaire, it was distributed after the end of the teaching unit. In the following table (see Table 12) there are the answers retrieved.

Table 12. Answers received by the questionnaire

\begin{tabular}{|c|c|c|c|}
\hline & & True & False \\
\hline $\begin{array}{c}\text { Before the } \\
\text { lesson }\end{array}$ & $\begin{array}{l}\text { I had no interest in working on unknown foreign } \\
\text { languages. }\end{array}$ & 16 & 78 \\
\hline \multirow{4}{*}{$\begin{array}{l}\text { During the } \\
\text { lesson }\end{array}$} & $\begin{array}{l}\text { I had the chance to use my previous knowledge on } \\
\text { foreign languages }\end{array}$ & 72 & 22 \\
\hline & I could easily pass from one language to another & 70 & 24 \\
\hline & $\begin{array}{l}\text { I realized that languages have not only differences but } \\
\text { also similarities }\end{array}$ & 83 & 11 \\
\hline & $\begin{array}{l}\text { I learnt to observe, analyze, detect similarities and } \\
\text { differences between languages }\end{array}$ & 85 & 9 \\
\hline After the & $\begin{array}{l}\text { I have no more prejudice against less common } \\
\text { languages }\end{array}$ & 73 & 21 \\
\hline
\end{tabular}




\begin{tabular}{|c|l|c|c|}
\hline lesson & $\begin{array}{l}\text { I was able to learnt some words in other foreign } \\
\text { languages than those I already knew }\end{array}$ & 80 & 14 \\
\cline { 2 - 4 } & $\begin{array}{l}\text { I discovered that there are also other related languages } \\
\text { to those I learn at school }\end{array}$ & 87 & 7 \\
\hline
\end{tabular}

As regards the pupils, according to the data retrieved from the questionnaires, the majority found the teaching unit pleasant, amusing and original, whereas pupils who found the unit boring, tiring and complicated were quite few. In addition, the pupils' majority claim having been able to use prior knowledge, filling the gap between unknown to known foreign languages, realizing that languages have not only differences but similarities as well.

\section{Conclusions}

A comparative consideration of the activities' results shows a considerable increase in pupils' performance. In particular, except for the first activity, which consists on a first auditory contact with the studied languages, from the second activity the pupils' scores increase noticeably, as the oral speech is combined with the written. The pupils' performance progress concerns each language and each activity. In particular, the high percentage of correct answers in the last activity proves that the previous activities which aimed at the pupils' familiarization with the studied languages through a cross-linguistic morphological and lexical approach, were comprehensible and effective.

At the end of this experience, the main conclusion that can be drawn is that Internet offers a range of free and accessible resources. As regards the multilingual competence, online machine translators appear to be an easy, quick and safe solution for vocabulary activities, aiming at a raise of awareness of multilingualism and of linguistic relations (similarities, differences, loan words). However, if it is about developing translingual abilities through working on sentences in order to study the syntax and the morphology of languages through a crosslinguistic approach, or even develop communicative competences in several languages, then in this case, teachers or any other person concerned should resort to native speakers, in order to assure the validity and objectivity of their work. Internet offers very important auxiliary tools for teaching materials' development for a multilingual awareness, provided that online translation tools are not considered as grist to the teacher's mill, but they are used in an appropriate way so as to equip teacher with valid and trustworthy material. Internet language resources in no case can they replace the language teacher; they can just offer them knowledge that they haven't. These resources can become precious tools, provided that they are used in a reliable, logical and adjusted to the teaching context. For all these reasons mentioned above, possibilities offered by free online translators are for the moment of a limited potential.

As far as it goes for the use of the free tools that Internet offers in order to integrate the plurilingualism in foreign language class, the important errors as well as the significant deviation from the correct linguistic form mainly concerning the sentences make us skeptical about the "blind" confidence on the validity of the linguistic material that they can offer.

\section{References}

[1] Anderson, Don D. (1995). "Machine translation as a tool in second language learning", CALICO Journal 13.1, 68-97.

[2] Cavalli, M. (2005). Éducation bilingue et plurilinguisme. Le cas du Val d'Aoste. Paris : Crédif Didier.

[3] Coste, D. (2001). "La notion de compétence plurilingue". Actes du séminaire "L'enseignement des langues vivantes, perspectives". Direction de l'Enseignement scolaire. Available at : http://eduscol.education.fr/index.php?./D0033/langvivacte3.htm

[4] Coste, D. (2002). "Compétence à communiquer et compétence plurilingue". In Castellotti, V. \& Py, B. (coord.). Notions en Questions (NEQ), $\mathrm{n}^{\circ}$ 6. pp. 115-123.

[5] Coste, D., Moore, and D., Zarate, G., (2009). Vers un Cadre Européen Commun de référence pour l'enseignement et l'apprentissage des langues vivantes: études préparatoires, Version révisée, Division des Politiques linguistiques, Strasbourg.

[6] Council of Europe (2001). Common European Framework of Reference for Languages: Learning, teaching, assessment. Cambridge University Press, Cambridge.

[7] Matthey, M., (2005). "Plurilinguisme, compétences partielles et éveil aux langues. De la sociolinguistique à la didactique des langues”. In M. Pouliot, E. Boulea et J.-P. Bronckart (dir.) : Repenser l'enseignement des langues : comment identifier et exploiter les compétences, Villeneuve d'Ascq, Presses universitaires du Septentrion, p. $135-159$

[8] McCarthy, B. (2004). "Does online machine translation spell the end of take-home translation assignments?" In CALL-EJ Online 6.1.

[9] Meihami, H., Husseini, F., (2014). "Bringing TTS software into the classroom: the effect of using text to 
speech software in teaching reading features", The journal of teaching English with Technology (TEwT), Volume 14 Issue 1, 23-34.

[10] Moore, D. (2003). Plurilinguismes et école. Représentations et dynamiques d'apprentissage. Habilitation à diriger des recherches. Paris : université Paris 3 - Sorbonne Nouvelle.

[11] Niño, A. (2004). "Recycling MT: A course on foreign language writing via MT post-editing". 7th Annual CLUK Research Colloquium, Birmingham, pages 179-187

[12] Niño, A. (2009). "Machine translation in foreign language learning: language learners' and tutors' perceptions of its advantages and disadvantages". ReCALL, 21, 241-258.

[13] Picardo, J., (2009). "Using Blogs and Voki to increase motivation and oral participation amongst boys in Modern Foreign Languages". 200375143 - MA ICT and Education - EDUC5979 1.

[14] Postholm, B., (2007). "The advantages and disadvantages of using ICT as a mediating artifact in classrooms compared to alternative tools". Teachers and Teaching, 13 (6), 587-599.

[15] Richmond, I.M. (1994). "Doing it backwards: Using translation software to teach target-language grammaticality". In Computer Assisted Language Learning 7, 65-78.

[16] Ryder, R. J., and Graves, M. F. (1997). "Using the Internet to enhance students' reading, writing, and information-gathering skills". Journal of adolescent \& adult literacy, 4(4), 244-254

[17] Shei, C-C, and Pain, H., (2001). "Learning a Foreign Language Through Machine Translation: Focusing on Sentence Stems and Collocations". AI-ED Workshop on CALL: Implementing Intelligent Language Tutoring Systems. May 19-23, 2001. San Antonio, US, http://www.geocities.ws/ccshei/publication/MTandEFL.ht $\mathrm{m}$

[18] Somers, H. (2003). Machine Translation in the Classroom. in Computers and Translation. A translator's guide. John Benjamins Publishing Company. Philadelphia, PA.

[19] Somers, H., F. Gaspari and A. Niño (2006) "Detecting Inappropriate Use of Free Online Machine Translation by Language Students - A Special Case of Plagiarism Detection". Proceedings of the 11th Annual Conference of the European Association of Machine Translation, Oslo University (Norway), $41-48$.

[20] Steding, S. (2009). "Machine Translation in the German Classroom: Detection, Reaction, Prevention". Teaching German, 42:2, 178-189.

[21] Tondeur, J., van Keer, H., van Braak, J. and Valcke, M., (2008). "ICT integration in the classroom: challenging the potential of a school policy". Computers \& Education, $51,212-223$. 